\title{
Linguistics landscape: A cross culture perspective
}

\author{
Max Ronald Duizenberg
}

Universiteit van Amsterdam, Amsterdam, Netherlands

\begin{abstract}
This paper was to aim in discussing the linguistic landscape. It was the visibility and salience of languages on public and commercial signs in a given territory or region (Landry and Bourhis 1997). The linguistic landscape has been described as being somewhere at the junction of sociolinguistics, sociology, social psychology, geography, and media studies. It is a concept used in sociolinguistics as scholars study how languages are visually used in multilingual societies, from large metropolitan centers to Amazonia. For example, some public signs in Jerusalem are in Hebrew, English, and Arabic (Spolsky and Cooper 1991, Ben-Rafael et al., 2006). Studies of the linguistic landscape have been published from research done around the world. The field of study is relatively recent; the linguistic landscape paradigm has evolved rapidly and while it has some key names associated with it, it currently has no clear orthodoxy or theoretical core.
\end{abstract}

Keywords---Amazonia, multilingual, orthodoxy, paradigm, sociolinguistics.

\section{Introduction}

At present in the era of globalization we get involved in the process of interference and interpretation of different cultures. This process finds its way in the linguistic changes such as appearance of a considerable amount of foreign words (borrowings), their implementation and usage by native speakers (mother-tongue speakers) and these borrowings fixation in the (national) language of the country in a short period (De Oliveira et al., 2006; Przymus \& Kohler, 2018). First of all new alien words widen the lexical-semantic groups related to developing spheres of social life such as science and engineering (information technology, in particular), economics and finance, mass culture, sports, politics and government, medical industry.

Generally speaking, the attempt to address varied topical issues may be justified by understanding that the theory and modern methodology of the linguistic landscape cannot be put into a certain and elaborated paradigm. Scholars argue 
that there is no universal concept-base inventory, which could support the coordinated study of this specific related issue. From the diachronic perspective, the studies of the Russian sociolinguist B. Larin on dialectal profile of the city and its social groups of population (Project team "Language of the city" worked at the History of Arts Institute as early as in 1926-1931), then studies of the Chicago School of urban sociology (1920-1930), and to some extent, the research works of W. Labov (1960s), the founder of the American sociolinguistics, contributed into understanding of differentiation between codes of meaning construction by various social strata of the city population. The resulting statement of previous studies evidenced that "spaces are constructed not just trough the objects and boundaries that surround us and the habitual ways we conceive of them, but also through interaction with others operating in the "same" space" (Ben-Rafael, Shoamy \& Barni, 2010).

\section{Method}

Scholars from many areas are tempting to exhibit a systematic description of linguistic profiles of present-day cities. It should be mentioned that the so-called "Linguistic landscape" has recently developed as a zone of cooperation among a wider spectrum of specialists. Sociolinguists, involved into studies of the interdependence of all kinds of social and linguistic phenomena paid attention to the fact that public spaces are marked by linguistically formulated symbols, which relate to many social, economic, political and cultural grounds (Ben-Rafael et al., 2006; Shoamy \& Gorter, 2008).

Thus, one of the definitions of linguistic landscape, under which the abovementioned scholars assume linguistic objects that mark public spaces with tokens, includes "any written sign found outside private homes, from road signs to names of streets, shops, and schools. The study of linguistic landscapes focuses on analyzing these items according to the language utilized, their relative saliency, syntactic or semantic aspects (Palang et al., 2011; Maruani \& AmitCohen, 2013). These language facts which landmark the public space are social facts that, as such, relate to more general social phenomena". It is understood, that further development of the linguistic landscape will depend on the consolidated contribution of different disciplinary areas. Their common understanding of linguistic landscape as the symbolic frame of public spaces motivated us to look at the city of Krasnoyarsk as a relevant social environment domiciled by people who live there and those who work there as advertising agents, designers of all kinds, investors and sponsors, local authorities, entrepreneurs and shop owners. We can, therefore, argue that the linguistic landscape is a kind of a crossroad of professional and social interests.

\section{Discussion}

The concept of cultural identity as a key factor of personal, social and national self-identification has acquired a special meaning in the era of globalization. Political, geographic, social and cultural community borders get crossed ever so often as people become part of the global employment market. Therefore it is essential to understand the mechanisms of change taking place in the cultural identities of migrants and recipient nations' representatives (Aristova, 2016; 
Takhtarova et al., 2015). This will be looking at definitions of cultural identity, study cultural identifiers and linguistic components making up its essence to answer the questions: The easiest way to define cultural identity would probably be to say that it means the feeling of belonging to a certain social or cultural group. Such deliberate simplification of this term would then require a lot of extra information to clarify what exactly one is dealing with.

According to Oxford Dictionary of Media and Communication, it is "the definition of groups or individuals (by themselves or others) in terms of cultural or subcultural categories (including ethnicity, nationality, language, religion, and gender) and in stereotyping, this is framed in terms of difference or otherness" (Chandler and Munday, 2011). Being an integral part of any person's selfconception/self-perception, it is undoubtedly related to nationality, ethnicity, religion, social class, generation, locality or any kind of social group that has its own distinct culture (Moha, 2005). What is essential, however, is the mechanism of creating notions of cultural differences or similarities. Therefore, in our research, we will be looking at cultural identity as a sociolinguistic factor either bringing individuals together based on a shared cultural mindset/ language/ lifestyle/traditions, etc. or alienating people from their original social and cultural communities in the case of sociolinguistic migration and other factors caused by worldwide globalization processes.

In recent decades that were marked by a very tangible rise of globalization processes throughout the world, a lot of research has been conducted to analyze the social and cultural impact of migration, resulting in conventional world culture map breakdown. Following J. Blommaert's idea that the global world "has not become a village, but rather a tremendously complex web of villages, towns, neighborhoods, settlements connected by material and symbolic ties in often unpredictable ways" (Blommaert, 2010), it is becoming ever more obvious that to understand this complexity and evaluate the consequences of these new social tendencies adequately, a more versatile and in-depth sociolinguistic analysis is required.

An individual as a subject and object of globalization needs to be identified/selfidentified by a whole new set of identity markers. Therefore new forms of identification emerge breaking down the understanding of an individual as a coherent whole subject into a collection of various cultural identifiers (location, gender, race, history, nationality, language, sexuality, religious beliefs, ethnicity, aesthetics, etc) (Duff, 2003; Grishaeva, 2015). But taken separately, all these identifiers subsequently bring together a solid picture of a person as an active participant in the global world. According to P. James, "categorizations about identity, even when codified and hardened into clear typologies by processes of colonization, state formation or general modernizing processes, are always full of tensions and contradictions.

Sometimes these contradictions are destructive, but they can also be creative and positive". The undoubtedly positive side of having to deal with the new global reality of often contradictory and elusive phenomena is that it calls for a more anthropocentric approach, making an individual (with his/her own set of cultural 
identifiers including language) the key figure in shaping not only local communities but drawing a whole new picture of a global world.

Language is undoubtedly the main component of cultural identity, as it generally originates and develops from the need to communicate, connecting people residing in a common given location at a particular period. Unlike citizenship, place of residence, way of life that may all be changed by a migrant person over a relatively short time, language takes time to both to learn and unlearn. Therefore a common language is an indispensable tool allowing people to share a way of life established by members of a certain social group, nation or community. It also gives almost unrestricted access to the cultural heritage of a nation, being both a reservoir of culture and a way to retrieve cultural artifacts of the nation's past.

\section{Landscape biographies as a bridging tool}

One of the most promising ways to bridge the above-mentioned gap is the concept of the cultural biography of landscapes. Landscape biographies show similarities with the British method of Historic Landscape Characterisation (HLC), but the latter focuses on the material landscape and is more of an implementation method (Clark et al., 2004). Based on the geographical ideas of geographer Samuels and anthropologists Kopytoff and Appadurai, a group of Dutch researchers has further developed and tested the idea that cultural landscapes bear the multilayered imprint of numerous generations of human "authors": landscape as a palimpsest (Bloemers et al., 2010). For a thorough understanding of these landscapes, I should not only investigate the physical remains of these "handwritings", but also the social backgrounds and cultural history of their authors.

From this point of view, landscapes should be explored from three different ontological dimensions (Jacobs, 2006). First, there is the physical dimension of the landscape, the immediately tangible landscape around us that can be called "matter-scape". This dimension has traditionally been studied by the natural sciences and classical geography, taking a highly empirical, objectivist and positivist approach to their research. Conclusions drawn in this dimension tend to be deemed scientifically "true" or "false". Second, there is the social dimension of landscape, which we could call "socio-scape" or "power-scape", comprising all the invisible norms, values, meanings and attitudes which surround the physical landscape, as it were, and are studied mainly by social scientists. This is a more subjective world, where conclusions are not so much true or false as they are, in more normative terms, "right" or "wrong".

Finally, there is a third, more individual dimension: the "mindscape", in which individual perception of the landscape is key. It is fed by both nature and nurture and is thus highly influenced both by our genes and by our individual life history. This dimension is studied by environmental psychologists and is reflected not only in personal feelings and behavior but also in more sublimated forms in literature, music, art and other forms of creative expression of the human mind (Gorter, 2018; Pahl, 2004). It centers mainly on authenticity and genuineness. In this interpretation, a cultural landscape biography is both a description of the 
history of the material landscape and of the world of social meanings and individual ideas grafted onto that landscape during various periods.

During the last decade, several interdisciplinary research teams have tried to develop regional landscape biographies in several parts of The Netherlands, combining geological, archaeological, historical-geographical, linguistic and anthropological approaches. Besides the critical interactions between the three landscape dimensions mentioned above, one of the most promising aspects of these biographies have been the interaction between expert knowledge and local knowledge (see Elerie and Spek, 2010). Compared with scientific knowledge, local knowledge is more individually based, more mixed with emotion, more locally than regionally determined, and more focused on a short-term genealogical perspective of one or two generations than on the diachronic development of centuries. Local knowledge also consists of a mix of historical facts, historical narratives (anecdotes, legends, folk tales), images, and meanings associated with certain individuals or groups. This is also reflected in the landscape biography which reveals both the continuous biographical timeline of the scientistsand the more place-oriented, unique individual narratives and meanings of residents and other local experts. Recent experiences have shown that, for instance, historical field names (toponyms) are an excellent research topic on the interface between local and expert knowledge, containing many elements from the physical, social, as well as the inner dimensions of landscape (Elerie and Spek, 2010).

\section{Linguistic landscapes and environmental print}

Some researchers have taken materials from signage in public spaces into the schools to use them as learning materials and others have taken students out of the classroom to explore the linguistic landscapes outside the school or a combination of both. As the studies below demonstrate, the linguistic landscape can be used for language learning, but even more as a powerful pedagogical tool to answer questions about language awareness, multilingual literacy, multimodality, identities, ideologies or the functions of signs (Enfield, 2008).

A team of Canadian researchers documented literacy practices of bilingual and multilingual children from two elementary schools, one with a French immersion program in Vancouver and the other from a multicultural neighborhood in Montreal (Dagenais et al., 2009). Based on ideas about the city as a text, they gave 10-11-year-olds the task to examine language diversity in their community by taking photographs of signage that surrounds them. Through the intervention, the children became more aware of the urban diversity and they learned to see their cities as "dense with signs that must be deciphered, read and interpreted" (Dagenais et al., 2009).

The researchers concluded that linguistic landscapes are useful in language awareness activities from a critical perspective. The study by Dagenais et al. (2009), of course, brings to mind the tradition of work on 1environmental print, which includes logos, words, labels, etc. and which is related to the development of youngreaders literacy skills in English monolingual contexts. For example, Giles and Tunks (2010) point to the research into the role of environmental print 
in literacy development and the benefits exposure it provides for emergent readers.

\section{Linguistic landscapes and English as a foreign language (EFL)}

English as a global language can be found in linguistic landscapes around the world and it is a recurring theme of many linguistic land-scape studies (Gorter, 2013). So it is not surprising that signage has found an application in English as a Foreign or a Second Language(EFL/ESL) classes for university students. For example, Sayer (2010) engaged his students as language investigators in a research project in Oaxaca, Mexico. The linguistic landscape became a pedagogical resource, where the students learned to connect language in the street to the language of the class. Sayer reported how the students looked into the purposes, intended audiences and different meanings of English on signs in a predominately Spanish environment. His project allowed students to reflect critically on the English language.

In a similar vein, but through virtual means, Malinowski (2010) reported on the Culture in Place project, in which English learners in Korea interacted through a dedicated website with Korean learners at a university in the US and where they discussed Korean-English images from signs in the linguistic landscape to foster reading abilities, develop fluency in the target language and enhance the learners 1 motivation by using real places and activities. In an EFL class of Japanese university students, Rowland (2013) required a group of students to photograph and analyze English used on signs. The students were asked to answer the question "How and why is English used on signs in Japan?" His students collected public texts, such as advertisements and road signs, and discussed them in the EFL class. His study supported the idea that pedagogical linguistic landscape projects, in particular from authentic, contextualized multilingual input, can have benefits for EFL students in the development of students' symbolic competence and critical literacy skills. Rowland could corroborate the claims that language learners can benefit from the visual and literacy materials from the linguistic landscape. Another example comes from the publication by Barrs (2016) who described a third-year class on World Englishes in which a group of 20 Japanese university students had to photograph examples of English inscriptions from the linguistic landscape and then write a short 50100word description about each inscription. In the class, the students carried out simple categorizations and basic analyses. The aim was not to learn English but to help the students in choosing a topic for their graduation thesis.

\section{Intertextuality}

Pop-culture talk is, of course, pervasive in modern (or postmodern) society and discourse across a variety of social settings. Thus, at a certain level, these examples are unremarkable and are easily interpreted by most readers of this article. However, the increasing presence of pop culture and its multiple functions and forms within mainstream classroom discourse have not been adequately explored by applied linguists and educators, particularly given the growing diversity of our student population and what appears to be the ever-growing role of pop culture in the lives and texts of young people today. Intertextuality 
involving pop culture typically connected with American movies and television programs is a powerful resource for the display of teachers' and students' social and cultural identities and affiliations (Maybin \& Mercer, 1996) and also a potential source of consternation for those who do not have insider knowledge of the pop culture texts under discussion.

\section{Narrative, ethnography and new literacy studies}

This research study also built on the New Literacy Studies (Barton \& Hamilton, 1998; Street, 1993) and involved ethnographic research. I related my research to ethnographic studies of literacy practices in homes, such as Rogers (2003), that used Critical Discourse Analysis and ethnography to create a multilayered narrative of a family's life, but widened the scope of the study to include multimodal texts (Kress, 1997). My approach to the narrative was informed by research in this field, which is associated with the ethnography of communication and with the linguistic anthropology of education (Wortham, 2003). This is research that has taken as its primary focus on educational practices and inequality (Cazden, 1996; Hymes, 1996; Michaels, 1986; Wortham, 2001). This literature was used in this study to identify narrative as an iterative form and to focus on out-of-school narratives. I drew, in particular, on studies considering communicative practices alongside literacy practices, such as Moje (2000). Studies (Dyson, 2003) considering the out-of-school communicative practices of children, young people and adults have increasingly considered how visual and linguistic modes interact and work together in communicative landscapes.

Duranti and Ochs described literacy practices in homes using a more visually oriented language of description in a study of Samoan communicative practices in a Californian suburb (Duranti \& Ochs, 1996). Their work was constructive in drawing attention to the importance of analyzing the relationship between the linguistic and the visual. When I entered the homes in this study, I paid attention to artifacts on walls and behind glass cabinets, as well as drawings, talk and other communicative practices, which carried symbolic meaning. As part of the study, a focus on narrative texts emerged. By identifying narrative aspects of parents' talk, children's text-making could be understood as being bound up with those narratives, and related to them. Texts were understood as relating to social practices, connected to the settled dispositions, or the habitus of the household (Bourdieu, 1990). Long-running narratives, upheld and framed by parents, gave the context for children's written and visual texts within home settings. Stewart's account of, 'narratives of the miniature' enabled me to identify how, in many households, objects 'told a story' (Stewart, 1993). They often 'held' the habitus of the family and were resonant with the narrative.

Since the beginning of the 1990s, Israel, and especially the Tel Aviv metropolitan region (TMR) at its core, has been experiencing accelerated development due to significant shifts in land and planning policies (Maruani \& Amit-Cohen, 2010). Most of the new development projects were erected on agricultural lands that had been converted for building and infrastructure purposes. The influx of planning and building during the decade 1990-2000 resulted in many development projects, mostly residential, that was ready to be marketed toward the end of the 1990s and the beginning of the 2000s, competing for potential buyers' attention. 
As an outcome, aggressive advertising campaigns were launched, in measures unprecedented in Israel until then. These campaigns mainly used means such as advertisements in newspapers, large roadside billboards, designated publications and special promotional real estate supplements that were distributed along with daily newspapers. Quite remarkably, many of these campaigns and advertisements made use of signs that expressed and represented landscape values in diverse forms, some of them highlighting the rural or agricultural character of the site while others emphasizing adjacent natural landscapes, cultural or historical values, or man-made parks within the project. In this context, 'landscape values' express a social construction of human-landscape relationships, implying the importance attached to landscape aspects that symbolize and reflect human socio-cultural needs, desires, ideas and concepts (Stephenson, 2008).

The use of landscape values in real estate advertising is not specific to Israel (see e.g., Collins \& Kearns, 2008; Eyles, 1987; Perkins, Thorns, \& Newton, 2008). This is not surprising given that landscape features are generally perceived as appreciated assets by the public (Jim \& Chen, 2009; Kaplan \& Austin, 2004), which is expressed, among others, by willingness to pay higher prices for properties with scenic views either of natural landscapes or urban open space (Bengochea Morancho, 2003; Crompton, 2001; Geoghegan, 2002; Jim \& Chen, 2006, 2009, 2010; Luttik, 2000; Portnov, Odish, \& Fleishman, 2005; Tyrväinen \& Miettinen, 2000). Moreover, similar findings keep on piling (see e.g., Larson \& Perrings, 2013; Melichar \& Kaprová, 2013). Developers are aware of this preference and use it for promoting their projects. In other words, the use of landscape values in advertising reflects the attractiveness of landscape features to prospective real estate buyers.

Intentionality, being a core segment in the activity of the human mind, bears epistemic significance, which can be exploited in the study of language. (Xu, 2013) As the first step in a specific mental activity and throughout the whole process, the intentionality frame, including intentional content and intentional attitude, can be regarded as a definite structure in the human mind and this renders it rather easy to ascertain in the analysis of the linguistic landscape.

Currently, the popularity of English in China is unprecedented and has been fuelled by the recent political and social development of Chinese society in the context of globalization. In the case of the largest city in China and the eighthlargest city in the world-Shanghai, the foreign languages seem to be omnipresent in public spaces. Business is no exception to this so-called shopping paradise. When we walk through the shopping downtown areas there, we encounter an uncountable flood of shop signs containing the foreign linguistic data. In particular, there is hardly any situation in which the passer-by is not confronted with the foreign languages, translated, borrowed, or used as it is in business that has a kind of influence on most of everybody's aspects of daily life.

As a corollary one could assume that there is a considerable number of customers with proficient language skills in foreign languages. It might also be suggested that its visibility in shop signs has something to do with the actual business 
demands for their intended readers. In order to pursue this assumption, the present case study comes into sight from a synchronic analysis of commercial shop signs in the city department stores and malls to document the presence and status of foreign languages, to investigate if there is a discrepancy between the functions performed by foreign linguistic items on the shop signs and the overall intentional attitude and intentional content of customers towards this language situation in the commercial context.

The study of shop signs as linguistic landscape (LL) has been an emerging field of applied linguistics, mainly explores the symbolic and indexical meanings of linguistic signs displayed in the material world. Shop signs can be categorized as bottom-up signs (Gorter, 2006), private signs (Ben- Rafael et al., 2009, 2015) or private texts (Franco Rodriguez, 2009). According to Landry and Bourhis (1997: 27), shop signs reflect most saliently the linguistic reality of a particular territory. Since the end of the 1990s, research into the LL has been enjoying growing interest in sociolinguistics (Amer \& Obeidat, 2014). Researchers have analyzed shop signs from different perspectives. For instance, Jing (2017). study the linguistic material in 355 shop signs in Irbid (a city in north Jordan) to see the use of foreign elements in these signs. Al-Kharabsheh et al. (2008) investigate orthographic translation errors and problems in shop signs in the Jordanian public commercial environment. Trumper-Hecht (2009) investigates the linguistic landscape of Upper Nazareth, Israel, to show how the LL can be a site where identity is constructed by the two groups in the city and the "language battle" between Arabic and Hebrew which reflects the overall tension in Jewish-Arab relations. In a study conducted on the linguistic landscape of Taipei, Taiwan, Curtin (2009) shows how LL can be a site where particular ideologies are promoted. Lanza and Woldemariam (2009) study the LL of the downtown and main shopping areas of Mekele, Ethiopia to see how the linguistic landscape is indexical of linguistic ideologies. Li. S. (2015) examines the particular features of English used in the LL of Suzhou to explore how English as a global language is deconstructed and reconstituted.

Shanghai, situating on the banks of the Yangtze River Delta in Eastern China, which is widely regarded as the citadel of China's modern economy and also one of the most important cultural, commercial, financial, industrial and communications centers of China, could be an excellent place for the LL research. On one hand, it provides an ideal research angle to study the internationalization of China, as its commercial fields could fulfill all the criteria of language on display in a multilingual urban setting; on the other hand, the higher visibility of various shop signs with foreign linguistic items in Shanghai provide affordances to the study of the commercial functions performed by foreign languages and the linguistic attitudes of customers, especially the acceptance towards the language situation in the commercial context.

This article can contribute to the body of the LL research emerging in China, by taking a closer look at the social-cultural and economic implications of linguistic items on shop signs. Through the extensive on-the-spot investigation of people's reactions to shop signs, it is also intended to discuss the naming request and standardization of shop signs for the construction of language civilization in the current business context of China. 


\section{Conclusion}

The linguistic landscape is the "visibility and salience of languages on public and commercial signs in a given territory or region" (Landry and Bourhis 1997). The linguistic landscape has been described as being "somewhere at the junction of sociolinguistics, sociology, social psychology, geography, and media studies". It is a concept used in sociolinguistics as scholars study how languages are visually used in multilingual societies. The languages used in public signs indicate what languages are locally relevant, or give evidence of what languages are becoming locally relevant (Kasanga, 2012). In many multilingual countries, multilingual signs and packaging are taken for granted, especially as merchants try to attract as many customers as possible or people realize that they serve a multilingual community.

\section{Acknowledgments}

This work was supported by the Department of Linguistics in Universiteit van Amsterdam.

\section{References}

Al-Kharabsheh, A., \& Al-Azzam, B. (2008). Translating the invisible in the Qur'an. Babel, 54(1), 1-18.

Amer, F., \& Obeidat, R. (2014). Linguistic landscape: A case study of shop signs in Aqaba City, Jordan. Asian Social Science, 10(18), 246.

Aristova, N. (2016). Rethinking cultural identities in the context of globalization: linguistic landscape of Kazan, Russia, as an emerging global city. ProcediaSocial and Behavioral Sciences, 236, 153-160. https:/ / doi.org/10.1016/j.sbspro.2016.12.056

Barrs, K. (2011). Mobility in learning: The feasibility of encouraging language learning on smartphones. Reading, 228-233.

Ben-Rafael, E., \& Ben-Rafael, M. (2015). Linguistic landscapes in an era of multiple globalizations. Linguistic Landscape, 1(1-2), 19-37.

Ben-Rafael, E., Shohamy, E., Hasan Amara, M., \& Trumper-Hecht, N. (2006). Linguistic landscape as symbolic construction of the public space: The case of Israel. International journal of multilingualism, 3(1), 7-30. https:/ / doi.org/10.1080/14790710608668383

Blommaert, J. (2010). The sociolinguistics of globalization. Cambridge University Press.

Bourdieu, P. (1990). In other words: Essays towards a reflexive sociology. Stanford University Press.

Cazden, C. B. (1996). Communicative Competence, 1966-1996.

Chandler, D., \& Munday, R. (2011). A dictionary of media and communication. OUP Oxford.

Chen, S. M., \& Chen, J. H. (2009). Fuzzy risk analysis based on ranking generalized fuzzy numbers with different heights and different spreads. Expert systems with applications, 36(3), 6833-6842. https://doi.org/10.1016/j.eswa.2008.08.015

Clark, R. L. (2004). U.S. Patent No. 6,825,734. Washington, DC: U.S. Patent and Trademark Office. 
Collins, D., \& Kearns, R. (2008). Uninterrupted views: real-estate advertising and changing perspectives on coastal property in New Zealand. Environment and Planning A, 4O(12), 2914-2932. https://doi.org/10.1068\%2Fa4085

Cooper, R. L., \& Spolsky, B. (1991). The influence of language on culture and thought: Essays in honor of Joshua A. Fishman's sixty-fifth birthday. New York: Mouton de Gruyter.

Crompton, J. L., Lee, S., \& Shuster, T. J. (2001). A guide for undertaking economic impact studies: The Springfest example. Journal of travel research, 4O(1), 79-87. https://doi.org/10.1177\%2F004728750104000110

Curtin, D. (2009). Executive power of the European Union: law, practices, and the living constitution (Vol. 12). OUP Oxford.

Dagenais, T. R., \& Keller, N. P. (2009). Pathogenesis of Aspergillus fumigatus in invasive aspergillosis. Clinical microbiology reviews, 22(3), 447-465.

De Oliveira, V. M., Campos, P. R., Gomes, M. A., \& Tsang, I. R. (2006). Bounded fitness landscapes and the evolution of the linguistic diversity. Physica A: Statistical Mechanics and its Applications, 368(1), 257-261. https://doi.org/10.1016/j.physa.2005.11.058

Duff, P. A. (2003). Intertextuality and hybrid discourses: The infusion of pop culture in educational discourse. Linguistics and Education, 14(3-4), 231-276. https://doi.org/10.1016/j.linged.2004.02.005

Duranti, A., \& Ochs, E. (1996). Use and acquisition of genitive constructions in Samoan. Social interaction, social context, and language, 175-189.

Dyson, E. (2003). Esther Dyson's Monthly Report, vol. 21, No. 10, Nov. 25, 2003.

Elerie, H., \& Spek, T. (2010). The cultural biography of landscape as a tool for action research in the Drentsche Aa National Landscape (Northern Netherlands). The Cultural Landscape Heritage Paradox. Protection and Development of the Dutch Archaeological-historical Landscape and its European Dimension, 83-113.

Enfield, N. J. (2008). Linguistic categories and their utilities: The case of Lao landscape terms. Language Sciences, 30(2-3), 227-255. https://doi.org/10.1016/j.langsci.2006.12.030

Eyles, N. (1987). Late Pleistocene debris-flow deposits in large glacial lakes in British Columbia and Alaska. Sedimentary Geology, 53(1-2), 33-71. https://doi.org/10.1016/S0037-0738(87)80003-9

Geoghegan, J. (2002). The value of open spaces in residential land use. Land use policy, 19(1), 91-98. https://doi.org/10.1016/S0264-8377(01)00040-0

Giles, R. M., \& Tunks, K. W. (2010). Children write their world: Environmental print as a teaching tool. Dimensions of Early Childhood, 38(3), 23-29.

Gorter, D. (2013). Linguistic landscapes in a multilingual world. Annual Review of Applied Linguistics, 33, 190-212.

Gorter, D. (2018). Linguistic landscapes and trends in the study of schoolscapes. Linguistics and Education, 44, 80-85. https://doi.org/10.1016/j.linged.2017.10.001

Gorter, D. (Ed.). (2006). Linguistic landscape: A new approach to multilingualism. Multilingual Matters.

Grishaeva, E. B. (2015). Linguistic landscape of the city of Krasnoyarsk. ProcediaSocial and Behavioral Sciences, 200, 210-214. https://doi.org/10.1016/j.sbspro.2015.08.054 
Hamilton, B. H., \& Ho, V. (1998). Does practice make perfect?: Examining the relationship between hospital surgical volume and outcomes for hip fracture patients in Quebec. Medical care, 892-903.

Hymes, J. L. (1996). Teaching the child under six. Consortium Pub.

Jacobs, K., \& Steck, D. A. (2006). A straightforward introduction to continuous quantum measurement. Contemporary Physics, 47(5), 279-303.

Jim, C. Y., \& Chen, W. Y. (2009). Ecosystem services and valuation of urban forests in China. Cities, 26(4), 187-194. https://doi.org/10.1016/j.cities.2009.03.003

Jing, F. (2017). Investigating intentionality of linguistic landscapes from the multilingual commercial signs. International journal of linguistics, literature and culture, 3(5), 46-52.

Kaplan, R., \& Austin, M. E. (2004). Out in the country: sprawl and the quest for nature nearby. Landscape and urban planning, 69(2-3), 235-243. https://doi.org/10.1016/j.landurbplan.2003.09.006

Kasanga, L. A. (2012). Mapping the linguistic landscape of a commercial neighbourhood in Central Phnom Penh. Journal of Multilingual and Multicultural Development, 33(6), https:/ / doi.org/10.1080/01434632.2012.683529

Kress, G., Leite-Garcia, R., \& Van Leeuwen, T. (1997). Discourse semiotics. Discourse as structure and process, 257-291.

Labov, W. (1960). Language and social class.

Landry, R., \& Bourhis, R. Y. (1997). Linguistic landscape and ethnolinguistic vitality: An empirical study. Journal of language and social psychology, 16(1), 23-49. https://doi.org/10.1177\%2F0261927X970161002

Larson, E. K., \& Perrings, C. (2013). The value of water-related amenities in an arid city: The case of the Phoenix metropolitan area. Landscape and Urban Planning, 109(1), 45-55. https://doi.org/10.1016/j.landurbplan.2012.10.008

Luttik, J. (2000). The value of trees, water and open space as reflected by house prices in the Netherlands. Landscape and urban planning, 48(3-4), 161-167. https:/ / doi.org/10.1016/S0169-2046(00)00039-6

Malinowski, M. T. (2010). Existence theorems for solutions to random fuzzy differential equations. Nonlinear Analysis: Theory, Methods \& Applications, 73(6), 1515-1532. https://doi.org/10.1016/j.na.2010.04.049

Maruani, T., \& Amit-Cohen, I. (2010). Patterns of development and conservation in agricultural lands-The case of the Tel Aviv metropolitan region 19902000. Land Use Policy, 27(2), 671-679. https://doi.org/10.1016/j.landusepol.2009.09.001

Maruani, T., \& Amit-Cohen, I. (2013). Marketing landscapes: The use of landscape values in advertisements of development projects. Landscape and urban planning, 114, https://doi.org/10.1016/j.landurbplan.2013.02.012

Melichar, J., \& Kaprová, K. (2013). Revealing preferences of Prague's homebuyers toward greenery amenities: The empirical evidence of distance-size effect. Landscape and Urban Planning, 109(1), 56-66. https://doi.org/10.1016/j.landurbplan.2012.09.003

Mercer, N., \& Maybin, J. (Eds.). (1996). Using English from conversation to canon (Vol. 2). Psychology Press. 
Michaels, E. (1986). The aboriginal invention of television in Central Australia, 1982-1986: report of the Fellowship to Assess the Impact of Television in Remote Aboriginal Communities. Canberra: Australian Institute of Aboriginal Studies.

Moha, N., \& Guéhéneuc, Y. G. (2005, July). On the automatic detection and correction of software architectural defects in object-oriented designs. In Proceedings of the 4th ECOOP Workshop on Object-Oriented Reengineering.

Moje, E. B. (2000). " To be part of the story": The literacy practices of gangsta adolescents. Teachers college record, 102(3), 651-690.

Morancho, A. B. (2003). A hedonic valuation of urban green areas. Landscape and urban planning, 66(1), 35-41. https://doi.org/10.1016/S0169-2046(03)000938

Pahl, K. (2004). Narratives, artifacts and cultural identities: An ethnographic study of communicative practices in homes. Linguistics and Education, 15(4), 339-358. https://doi.org/10.1016/j.linged.2005.07.002

Palang, H., Spek, T., \& Stenseke, M. (2011). Digging in the past: New conceptual models in landscape history and their relevance in peri-urban landscapes. Landscape and urban planning, 100(4), 344-346. https://doi.org/10.1016/j.landurbplan.2011.01.012

Perkins, H. C., Thorns, D. C., \& Newton, B. M. (2008). Real estate advertising and intraurban place meaning: real estate sales consultants at work. Environment and Planning A, 40(9), 2061-2079. https://doi.org/10.1068\%2Fa39191

Portnov, B., Genkin, B., \& Barzilay, B. (2009). Investigating the effect of train proximity on apartment prices: Haifa, Israel as a case study. Journal of Real Estate Research, 31(4), 371-395.

Przymus, S. D., \& Kohler, A. T. (2018). SIGNS: Uncovering the mechanisms by which messages in the linguistic landscape influence language/race ideologies and educational opportunities: Linguistics and education. Linguistics and Education, 44, 58-68. https://doi.org/10.1016/j.linged.2017.10.002

Rodriguez, J. M. F. (2009). Interpreting the linguistic traits of linguistic landscapes as ethnolinguistic vitality: methodological approach. RAEL: revista electrónica de lingüística aplicada, (8), 1-15.

Rogers, E. M., \& Singhal, A. (2003). Empowerment and communication: Lessons learned from organizing for social change. Annals of the International Communication Association, 27(1), 67-85. https://doi.org/10.1080/23808985.2003.11679022

Rowland, A., Miners, J. O., \& Mackenzie, P. I. (2013). The UDPglucuronosyltransferases: their role in drug metabolism and detoxification. The international journal of biochemistry \& cell biology, 45(6), 1121-1132. https://doi.org/10.1016/j.biocel.2013.02.019

Sayer, N. A., Noorbaloochi, S., Frazier, P., Carlson, K., Gravely, A., \& Murdoch, M. (2010). Reintegration problems and treatment interests among Iraq and Afghanistan combat veterans receiving VA medical care. Psychiatric services, 61(6), 589-597.

Shohamy, E. G., Rafael, E. B., \& Barni, M. (Eds.). (2010). Linguistic landscape in the city. Multilingual Matters.

Shohamy, E., \& Gorter, D. (Eds.). (2008). Linguistic landscape: Expanding the scenery. Routledge.

Stephenson, J. (2008). The Cultural Values Model: An integrated approach to values in landscapes. Landscape and urban planning, 84(2), 127-139. https://doi.org/10.1016/j.landurbplan.2007.07.003 
Stewart, S. (1993). On longing: Narratives of the miniature, the gigantic, the souvenir, the collection. Duke University Press.

Street, B. V. (Ed.). (1993). Cross-cultural approaches to literacy (No. 23). Cambridge University Press.

Takhtarova, S. S., Kalegina, T. E., \& Yarullina, F. I. (2015). The role of English in shaping the linguistic landscape of Paris, Berlin and Kazan. Procedia-Social and Behavioral Sciences, 199, 453-458. https://doi.org/10.1016/j.sbspro.2015.07.531

Trumper-Hecht, N., Shohamy, E., \& Gorter, D. (2009). Language landscape: Expanding the scenery.

Tyrväinen, L., \& Miettinen, A. (2000). Property prices and urban forest amenities. Journal of environmental economics and management, 39(2), 205223. https://doi.org/10.1006/jeem.1999.1097

Woldemariam, K. M., \& Yen, G. G. (2009). Vaccine-enhanced artificial immune system for multimodal function optimization. IEEE Transactions on Systems, Man, and Cybernetics, Part B (Cybernetics), 4O(1), 218-228.

Wortham, S. E. F. (2001). Narratives in action: A strategy for research and analysis. Teachers College Press.

Wortham, S. E. F., \& Rymes, B. (Eds.). (2003). Linguistic anthropology of education. Praeger Publishers.

Xu, M., Liang, T., Shi, M., \& Chen, H. (2013). Graphene-like two-dimensional materials. Chemical reviews, 113(5), 3766-3798.

Zhou, G., Li, L., Ma, C., Wang, S., Shi, Y., Koratkar, N., ... \& Cheng, H. M. (2015). A graphene foam electrode with high sulfur loading for flexible and high energy Li-S batteries. Nano Energy, 11, 356-365. https://doi.org/10.1016/j.nanoen.2014.11.025 